\title{
Surveying the occurrence of subspontaneous glyphosate-tolerant genetically engineered Brassica napus L. (Brassicaceae) along Swiss railways
}

Nicola Schoenenberger ${ }^{1^{*}}$ and Luigi D'Andrea ${ }^{2^{*}}$

\begin{abstract}
Background: Railway tracks represent a highly interlinked habitat with numerous possibilities for accidental entry of oilseed rape due to seed spill during transportation. Moreover, glyphosate is regularly employed to control the vegetation, increasing the possibility of establishment for plants resistant to it. We surveyed the presence of genetically engineered glyphosate tolerant oilseed rape (Brassica napus) with a focus on the most important Swiss railway stations. Our objective was to detect accidental establishment of transgenic plants, since Switzerland does not import nor cultivate transgenic oilseed rape.
\end{abstract}

Results: Seventy-nine railway areas were sampled in Switzerland and the Principality of Liechtenstein, and the feral presence of oilseed rape was detected in 58 of them. A total of 2403 individuals were tested for genetic modification using commercially available immunologic test kits. In four localities, one located in Lugano and three in the area of Basel, a total of 50 plants expressing the CP4 EPSPS protein were detected. In two of the localities, survival of herbicide applications was observed. The populations were probably introduced through contaminated seed spills from freight trains, or during the transfer of goods from cargo ships to trains.

Conclusions: Railways represent an ideal system for herbicide resistant transgenic plants to establish and spread as a result of high selective pressure in favour of herbicide resistance with consequent increased difficulties to keep the infrastructure free of weeds. Crop-to-wild gene flow can occur as several sexually compatible species which are congeneric or in allied genera to oilseed rape were found growing sympatrically. Moreover, the capillary presence of railways in the agricultural landscape provides a putative source of contamination of GE-free agriculture. Our results suggests that carefully adapted monitoring designs may be set in order to detect introduction events that can lead to rapid establishment and growing populations as the accepted contamination thresholds are likely to be biologically insufficient to prevent further environmental contamination.

Keywords: Brassica napus, Oilseed rape, Canola, Genetically modified crop, Seed loss and spillage, Environmental contamination, Railway

\footnotetext{
*Correspondence: schoenenberger@innovabridge.org; dandrea@biomeconseils.ch

${ }^{1}$ InnovaBridge Foundation, Via Rompada 40, 6987 Caslano, Switzerland ${ }^{2}$ BIOME, Rue des Bocages 9, 2800 Delémont, Switzerland
} 


\section{Background}

\section{General situation}

Global cultivation of oilseed rape (Brassica napus L.) has been gradually increasing over the last 10 years, reaching about 31.5 Mha in 2010 [1]. In 2011, 26\% of the global land area dedicated to oilseed rape was cropped with genetically engineered (GE) cultivars; these cultivars are mainly designed for tolerance to either glyphosate (GLY) or gluphosinate (GLU) [2,3], referred to as genetically engineered herbicide tolerant (GEHT) cultivars. This represents roughly $8 \mathrm{Mha}$, or $5 \%$ of the global biotech crop area. Presently, the import and processing of three GE-oilseed rape cultivars is permitted in the European Union (EU). Of these cultivars, two are authorised as animal feedstuff, whilst the authorisation for use as food is under renewal (events GT 73 and MS8xRF3), whereas one cultivar is currently authorised for processing into both human food and animal feed (event T45). Cultivation is forbidden for any GEoilseed rape cultivar [4]. Oilseed rape event GT73 is tolerant to the herbicide active substance GLY while the other two to GLU. However, several experimental releases of GE-oilseed rape in the environment were notified in the EU (a total of 379 between 1991 and 2008) mainly in France, UK, Belgium, Germany and Sweden [5].

\section{Situation in Switzerland}

In Switzerland, citizens approved a Popular Initiative in 2005 , to ban genetically modified organisms (GMO's) from Swiss agriculture for five years [6]. This ban has been extended by three years and is therefore valid until the end of 2013 [7]. Although some GE-Maize and Soybean cultivars are allowed in Switzerland for feed, and some GE-oilseed rape cultivars are tolerated as contaminants (see hereafter) [8], no GE-feed has been imported into the country since 2008 [9]; additionally, no GEoilseed rape imports are allowed for human consumption [10] Therefore, Switzerland is considered free of any cultivation and import of GE-crops. In 2009, Switzerland produced approximately 70'000 $\mathrm{t}$ of oilseed rape seeds; around 11'000 t were imported mainly for oil and biofuel production. Imports originated mainly from Hungary, Romania, Austria, Germany and Balkan countries. Switzerland does not import oilseed rape seeds from countries growing GE-oilseed rape on a large scale such as Canada or USA. Transportation occurs by truck and freight trains [Swiss Federal Office of Agriculture, personal communication]. In Switzerland labelling is required for any product used in the environment (including seeds) containing more than $0.1 \%$ authorised GE-cultivars [11], whereas in seed lots up to $0.5 \%$ impurities are tolerated for un-authorised varieties that have been approved by another state with a similar procedure as the Swiss [12] or whose environmental compatibility has been verified following [11]. In animal feed, impurities of up to $0.5 \%$ unauthorised GMO's are tolerated if these are authorised in the EU, whereas if not authorised in the EU, the Federal Administration can exceptionally allow the use of contaminated $(\leq 0.5 \%)$ feedstuff upon application, if the contained GE-varieties are permitted in the USA or Canada [13]. Moreover, labelling is required for feed containing more than $0.9 \%$ GE-ingredients [13].

\section{Environmental concern}

Transgenic crops are being increasingly produced in some parts of the world and imported to most others. A frequently recognized concern is the transfer of transgenic constructs from GE-crops to their wild relatives or to other crops by vertical gene flow, possibly leading to changes in the ecology of crop-related wild species following introgression $[14,15]$. The introgression into a wild relative of an herbicide resistance gene could lead to increased invasiveness and/or weediness of introgressants [16], with a potentially negative impact on the cropping system [17]. Risks of gene swamping or pollution of natural gene pools, leading to the extinction of wild taxa have also been stressed [14]. Similarly, escape of crop alleles through hybridisation has been shown and is thought to affect a large proportion of domesticated plants, at least in some part of their agricultural distribution [18]. Moreover GE-crops could differ from their non-GE-parent lines not only by the construct inserted, but also through unknown reorganisation of the genome caused by the random process of transformation [19]. Oilseed rape has numerous relatives which are congeneric or in allied genera. Hybridisation can occur with several species [20], most of which can be found as crops, growing subspontaneously in cultivated areas or wild in ruderal habitats.

\section{Cases of environmental escape}

Biological characteristics such as partial allogamy and zoogamy, tendency of pod shattering with consequent loss of seeds, ability to survive as volunteers and tendency to form feral populations contribute to making oilseed rape one of the crops with highest likelihood of uncontrolled dispersion of transgenes [21]. For instance, oilseed rape cultivars engineered for GLY or GLU herbicide tolerance escaped soon after their commercial release in Canada [22,23] or recently in the USA [24]. Cases of agricultural contamination by GE-oilseed rape also happened in Europe. In 2000, farmers in France, Germany, Sweden, UK and other European countries inadvertently planted large amounts of contaminated seeds Hyola 401 imported from Canada by the Dutch-owned Advanta Company. In 2007, Deutsche Saatgutveredlung 
Table 1 Distribution of the sample sites and detection of transgenic and non-transgenic oilseed rape in Switzerland

\begin{tabular}{|c|c|c|c|c|c|c|}
\hline Sampling date & Place (railway area) & Coordinates $\mathrm{x}$ & Coordinates y & Canton or country & Sample size & Positive samples \\
\hline 16.05 .2012 & Biel & 585157 & 220177 & $\mathrm{BE}$ & 1 & 0 \\
\hline 16.05 .2012 & Burgdorf & 613671 & 212235 & $\mathrm{BE}$ & 41 & 0 \\
\hline 16.05 .2012 & Bützberg & 623810 & 228927 & $\mathrm{BE}$ & 3 & 0 \\
\hline 16.05 .2012 & Herzogenbuchsee & 619887 & 226449 & $\mathrm{BE}$ & 55 & 0 \\
\hline 16.05 .2012 & Langenthal & 626063 & 229594 & $\mathrm{BE}$ & 2 & 0 \\
\hline 02.05 .2012 & Basel, Birsfelden port & 615054 & 267392 & $B L$ & 95 & 0 \\
\hline 10.05 .2012 & Muttenz, marshalling yard & 616412 & 264579 & $\mathrm{BL}$ & 29 & 0 \\
\hline 10.05 .2012 & Muttenz, Auhafen (port area) & 616810 & 265564 & $\mathrm{BL}$ & 47 & 1 \\
\hline 10.05 .2012 & Basel Bad & 612758 & 268594 & BS & 4 & 0 \\
\hline 10.05 .2012 & Basel SBB & 611364 & 266263 & BS & 7 & 0 \\
\hline 10.05 .2012 & Basel St. Johann & 609915 & 269330 & BS & 13 & 12 \\
\hline 02.05 .2012 & $\begin{array}{l}\text { Kleinhüningen, unloading } \\
\text { structure (port area) }\end{array}$ & 611308 & 270495 & BS & 18 & 16 \\
\hline 02.05 .2012 & $\begin{array}{l}\text { Kleinhüningen, marshalling } \\
\text { yard (port area) }\end{array}$ & 611248 & 269920 & BS & 58 & 0 \\
\hline 05.09 .2011 & Nendeln FL & 759335 & 229844 & $\mathrm{FL}$ & 2 & 0 \\
\hline 04.07 .2012 & Fribourg & 577920 & 183333 & $\mathrm{FR}$ & 2 & 0 \\
\hline 04.07 .2012 & Romont & 559641 & 171461 & $F R$ & 9 & 0 \\
\hline 27.06 .2012 & La Praille & 498597 & 114986 & GE & 60 & 0 \\
\hline 27.06 .2012 & Lancy Pont Rouge & 498641 & 116286 & GE & 18 & 0 \\
\hline 24.10 .2011 & Landquart & 761030 & 203698 & GR & 34 & 0 \\
\hline 06.11 .2011 & Delémont & 593355 & 245675 & $\mathrm{JU}$ & 28 & 0 \\
\hline 27.04 .2012 & Porrentruy & 572996 & 252459 & $J U$ & 61 & 0 \\
\hline 15.01 .2012 & Neuchâtel & 562051 & 205375 & $\mathrm{NE}$ & 7 & 0 \\
\hline 28.04 .2012 & Serrières & 559469 & 203881 & $\mathrm{NE}$ & 12 & 0 \\
\hline 05.09 .2011 & Buchs SG & 754630 & 226460 & SG & 100 & 0 \\
\hline 24.10 .2011 & Flums & 744965 & 217939 & SG & 154 & 0 \\
\hline 04.09 .2011 & Gossau & 737042 & 252783 & SG & 2 & 0 \\
\hline 04.09 .2011 & Rorschach & 755948 & 260637 & SG & 244 & 0 \\
\hline 24.10 .2011 & Sargans & 752606 & 212333 & SG & 3 & 0 \\
\hline 05.09 .2011 & St Margrethen & 766129 & 258112 & SG & 67 & 0 \\
\hline 04.09 .2011 & Wil SG & 720629 & 258091 & SG & 13 & 0 \\
\hline 23.10 .2011 & Ziegelbrücke & 722966 & 221924 & SG & 121 & 0 \\
\hline 04.09 .2011 & Schaffhausen & 690376 & 285153 & $\mathrm{SH}$ & 27 & 0 \\
\hline 04.09 .2011 & Thayngen & 694724 & 289087 & $\mathrm{SH}$ & 1 & 0 \\
\hline 23.10 .2011 & Pfäffikon & 701556 & 228891 & $S Z$ & 14 & 0 \\
\hline 22.01 .2012 & Bellinzona & 722882 & 117307 & $\mathrm{TI}$ & 9 & 0 \\
\hline 22.01 .2012 & Biasca & 718259 & 134376 & $\mathrm{TI}$ & 13 & 0 \\
\hline 15.05 .2012 & Cadenazzo & 716087 & 112364 & $\mathrm{TI}$ & 1 & 0 \\
\hline 15.05 .2012 & Castione - Arbedo & 723658 & 120471 & $\mathrm{TI}$ & 64 & 0 \\
\hline 06.09 .2011 & Lugano & 716852 & 95821 & $\mathrm{TI}$ & 23 & $21^{*}$ \\
\hline 15.05 .2012 & Manno & 714649 & 98108 & $\mathrm{TI}$ & 28 & 0 \\
\hline 15.11 .2011 & Taverne-Torricella & 715406 & 101579 & $\mathrm{TI}$ & 1 & 0 \\
\hline 25.06 .2012 & Denges & 530605 & 153150 & VD & 239 & 0 \\
\hline 27.06 .2012 & Etoy & 522313 & 147602 & VD & 29 & 0 \\
\hline 15.01 .2012 & Morges & 527479 & 151538 & VD & 34 & 0 \\
\hline 04.07.2012 & Moudon & 551445 & 168865 & VD & 35 & 0 \\
\hline
\end{tabular}


Table 1 Distribution of the sample sites and detection of transgenic and non-transgenic oilseed rape in Switzerland (Continued)

\begin{tabular}{|c|c|c|c|c|c|c|}
\hline 04.07 .2012 & Payerne & 562028 & 185585 & VD & 5 & 0 \\
\hline 25.06 .2012 & Renens & 534584 & 154082 & VD & 200 & 0 \\
\hline 25.06 .2012 & Yverdon & 539084 & 181527 & VD & 12 & 0 \\
\hline 23.10 .2011 & Rotkreuz & 675509 & 221810 & ZG & 5 & 0 \\
\hline 03.09.2011 & Bülach & 682490 & 264443 & $\mathrm{ZH}$ & 42 & 0 \\
\hline 03.09 .2011 & Dietikon & 672700 & 251498 & $\mathrm{ZH}$ & 31 & 0 \\
\hline 03.09 .2011 & Dübendorf & 689479 & 250582 & $\mathrm{ZH}$ & 1 & 0 \\
\hline 25.10 .2011 & Oberwinterthur & 699641 & 262822 & $\mathrm{ZH}$ & 91 & 0 \\
\hline 02.09 .2012 & Rümlang (field), NC & 682521 & 255467 & $\mathrm{ZH}$ & 5 & 0 \\
\hline 03.09 .2011 & Seebach & 683395 & 252558 & $\mathrm{ZH}$ & 15 & 0 \\
\hline 03.09 .2011 & Thalwil & 685176 & 238912 & $\mathrm{ZH}$ & 21 & 0 \\
\hline 03.09.2011 & Wezikon & 702345 & 241635 & $\mathrm{ZH}$ & 20 & 0 \\
\hline 25.10 .2011 & Winterthur & 696838 & 261918 & $\mathrm{ZH}$ & 50 & 0 \\
\hline 23.10 .2011 & Zürich Herdern-Hardbrücke & 681789 & 248627 & $\mathrm{ZH}$ & 77 & 0 \\
\hline Total & & & & & 2403 & 50 \\
\hline
\end{tabular}

Coordinates are expressed in the Swiss metric coordinates system; contry: FL = Fürstentum Liechtenstein; cantons: $\mathrm{BE}=\mathrm{Bern}, \mathrm{BL}=\mathrm{Basel}$ Landschaft, $\mathrm{BS}=\mathrm{Basel}$ Stadt, $F R=$ Fribourg, GE = Genève, GR = Graubünden, JU = Jura, NE = Neuchâtel, SG = St. Gallen, SH = Schaffhausen, $S Z=S c h w y t z, T I=T i c i n o, V D=V a u d, Z G=Z u g$, $\mathrm{ZH}=$ Zürich; $\mathrm{NC}=$ Negative Control.

* A specimen was deposited at the Herbarium of the Museum of Natural History in Lugano, Switzerland (LUG 19325).

sold contaminated seeds planted over at least 1500 ha [25, with more examples]. Moreover, GE-oilseed rape populations thrive along transport axes even in countries, such as Japan, where no GE-oilseed rape is grown [26]. Despite growing evidence and concern for the escape of GE-cultivars into the wild, monitoring surveys assessing transgene presence in feral populations in the European Union are lacking [27].

The aim of this study was to establish whether GEGLY-tolerant oilseed rape have established on Swiss railway tracks. Railway tracks represent a highly interlinked habitat with numerous possibilities for seed spill during transportation. Moreover, GLY is regularly employed (up to twice a year) to control the vegetation, hence increasing habitat suitability for plants resistant to this herbicide.

\section{Methods}

Railway stations and yards throughout Switzerland were visited during 2011 and 2012 (Figure 1, Table 1) and feral oilseed rape was sampled comprehensively. In case of small populations (generally $<100$ individuals) all detected plants were sampled. In the few very large populations detected, as e.g. in Rorschach (Table 1), samples were collected at regular distances of a few meters over the whole area were oilseed rape was growing. Freshly collected leaves were pooled (up to 6 individuals) and ground in a mortar and pestle in demineralised water or extraction buffer provided by the manufacturer of the test strips used (see hereafter). Supernatant liquid was transferred into plastic tubes and analysed with the Reveal ${ }^{\circledR}$ for CP4 (Roundup Ready ${ }^{\circledR}$ ) lateral flow strip test kit by Neogen Ltd. Glasgow, UK, or the Envirologix ${ }^{\circledR}$ QuickStix Kit for Roundup Ready ${ }^{\circledR}$ oilseed rape Leaf and Seed, distributed also by Neogen Ltd. The immunologic tests detect CP4 EPSPS, conferring glyphosate tolerance. Both kits were used according to the manufacturer's instructions and gave the same results. According to the same instructions, limit of detection in bulked samples of both the test strips used is $0.1 \%$. Before starting field work, the efficiency of the immunologic tests was confirmed in a laboratory using oilseed rape plants from a commercially grown field near Rümlang, Zurich, as negative control (Table 1), whereas the positive control consisted in certified reference 0304B Event GT73/RT73 oilseed rape Seed (Monsanto) by AOCS, Champaign, IL, USA. Positive reference seed was germinated in a petri dish and then transplanted in a soil-filled pot. Clearly readable positive test strip results (detection of CP4 EPSPS) were possible in a bulk of up to 12 leaves of which one was transgenic. During field work, the bulk samples collected in the railway areas which were positively tested, were tested again individually in order to retrieve the frequency of transgenic plants in single populations. A part of these positively tested samples were sent to the Cantonal Laboratory in Basel, Switzerland, for genetic analyses, particularly real time PCRs of the gox and cp4epsps transgenes and an event specific PCR of GT73 glyphosate tolerant oilseed rape, confirming the positive results generated with the test strips (data not shown). Herbarium vouchers were deposited at the Herbarium of the 


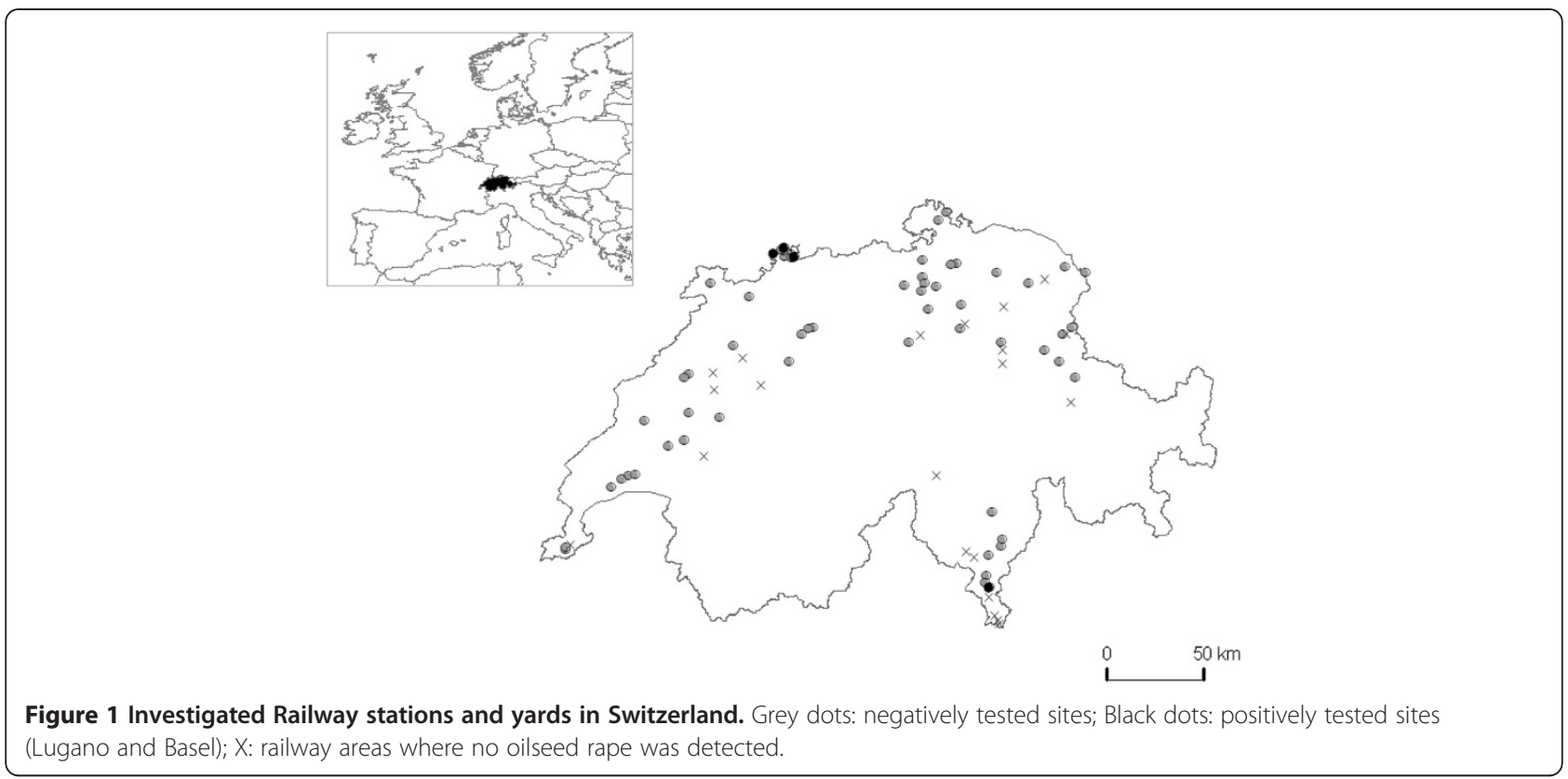

Cantonal Museum of Natural History in Lugano, Switzerland (Herbarium code: LUG).

\section{Results and discussion}

A total of 79 railway stations and areas in Switzerland and in the Principality of Liechtenstein were visited in 2011 and 2012 (Figure 1). The feral presence of oilseed rape was detected in 58 sites (73\%) and a total of 2403 individuals were tested for genetic modification (including negative control, Table 1). The presence of weedy oilseed rape in most of the locations is not surprising as oilseed rape has been transported for many years and populations are well established in many Swiss railway areas. In 21 stations (Airolo, Balerna, Bern, Bulle, Chiasso, Chur, Eaux-Vives, Glarus, Ins, Locarno, Lyss, Magadino - Vira, Melide, Mendrisio, Murten, Näfels, Rapperswil, Schaan, St. Gallen, Wattwil, Zug) we were unable to find any oilseed rape plants (Figure 1). The CP4 EPSPS enzyme was immunologically detected in 50 wild growing oilseed rape plants (2.1\% of total) distributed over 4 populations (Table 1 ). At the railway station of Lugano (Canton Ticino) 91.3\% of the plants were tested positive, at the unloading railway yard in the port of Kleinhüningen (Canton Basel Stadt) 88.9\%, at the railway station of St. Johann (Canton Basel Stadt) 92.3\% and at the railway yard in the port Muttenz-Auhafen (Canton Basel Landschaft) 2.1\%. All other tested sites were free from GE-oilseed rape. The detection of CP4 EPSPS and the fact that the GE- plants survived GLY treatment in Lugano (which took place in early September 2011) and in Kleinhüningen (in Mai 2012) suggest that the plants were expressing the transgenes at efficient levels. Although herbicides are regularly applied to all railway infrastructures in Switzerland to keep them functional, we did not directly observe treatments in St. Jakob and Muttenz. Only a subset of Swiss railway stations was sampled; nevertheless GEHT plants were found in four locations. This indicates that introduction events of GE-oilseed rape are still a rather rare event in the country and seem to happen predominantly in its important entry points of imported goods, like the Basel area. Transgenic oilseed rape is only recently become available and is transported in much smaller quantities than the conventional crop, and consequently has a lower incidence in railway ruderal habitats. However, it is conceivable that it is just a matter of time for transgenic populations to become more abundant considering the positive selective pressure, with consequent increased difficulties to keep the infrastructure free of weeds. A systematic long-term monitoring is therefore strongly recommended. The GE-populations did not establish through introductions of pure GMHT seeds as illustrated by the population in Muttenz, where only a low percentage of the plants was transgenic. Moreover, had all founder seeds been transgenic in populations with a high frequency of GE-plants (i.e. Lugano, Kleinhüningen and St. Johann), the presence of individuals not containing cp4 epsps genes would hardly be possible, as commercialised GE-oilseed rape contains the transgenes in a homozygous state, ruling out the possibility of genetic drift. More likely, the GE- populations established through introduction of few or even a single seed containing transgenes, followed by multiple cycles of reproduction.

The potential for persistence of GLY-tolerant genotypes at the expense of non-transgenic genotypes has 
been demonstrated experimentally, even in a scenario of GLY drift from field margins [28], and not direct application as it is the case on railway tracks. In Lugano, Kleinhüningen and St. Johann, the GMHT populations most probably underwent strong selection for the transgene, resulting in an enrichment of cp4 epsps genes in the population. Moreover, when positively selected by environmental conditions, not only the establishment of transgenes in a given population will increase, but its spread to other feral populations and possibly wild relatives could assume greater importance, too. In Ticino, oilseed rape has not been cultivated for several years [Office for agriculture of the Canton Ticino, personal communication]. However, we detected feral populations in several locations during a floristic survey of the Canton's railways in 2001-2003 [29,30]. At that time, no oilseed rape was growing at the railway station in Lugano, indicating that the detected GMHT population originated after 2003.

Our observations indicate that GE- oilseed rape may be capable of establishing self perpetuating populations outside agricultural areas, for instance on herbicidetreated railway tracks, infrastructures for the transfer of goods from ship to train, and surrounding disturbed habitats in Switzerland. Furthermore, these populations that are persistent from year to year may be capable of hybridizing to produce novel genotypes. GE-oilseed rape has been previously found growing along transport axes $[24,26]$. However, besides a single GE-oilseed rape plant found in the environment in Belgium [31], our results provide the first evidence of such an event in Europe, and put into perspective the assertion that "seed import spills of oilseed rape imports possibly containing GEmaterial will be mostly confined to port areas" [27]. Although oilseed rape seeds can be transported by birds and mammals or even dispersed through fireworks, feral oilseed rape growing on railway tracks most probably originate from seed spills during transportation or the transfer of goods. The persistence of a population in a given location is attributed to replenishment through fresh seed spill, emergence from the soil seed bank, shedding from feral mature plants, or to dispersal of feral seeds from one location to another [27]. As regards to the seed bank, studies in the northern hemisphere have reported viable seeds of oilseed rape persisting in disturbed soils for at least 5 years and possibly up to 10 years or more in undisturbed soil [32-34]. As a consequence, we suggest that every location where GEoilseed rape is found in Switzerland, monitoring and eradication should be carried out during a period of at least 10 years, as the elimination of feral unauthorised GE-populations is a legal requirement [11].

The opportunity to be transported from one available habitat to another is a key factor that could enable further colonization. Indeed, roads and railways interconnect anthropogenic ecosystems and facilitate the spread of plant species adapted to these [35]. This study provides further evidence to the general concern that transport axes act as a possible escape route for GEplants [36].

\section{Gene flow}

The possibility of vertical gene flow between oilseed rape plants, with wild relatives and with domesticated species has been extensively discussed in literature [e.g. 20,21,37]. Significant outcrossing between oilseed rape has been reported up to $100 \mathrm{~m}$, and exceptional outcrossing up to $26 \mathrm{~km}$ (reviewed in [21]). In Switzerland, railways often run in agricultural areas; such gene flow from GE-oilseed rape present on the railway infrastructure to adjacent organic and conventional agricultural fields may be of concern, particularly if GE-populations were to increase substantially under strong selection pressure [38]. Oilseed rape is not grown for seed production in Switzerland [SwissOlio Bern, personal communication], and therefore an eventual contamination of agricultural fields would mostly be interrupted by harvesting and processing. Nevertheless, the negative publicity connected with findings of uncontrolled GMO's in the environment could seriously damage the Swiss oilseed rape industry, considering the high sensitivity of consumers regarding GE-food at the European scale [39].

A further source of concern is the potential for hybridisation with related species. In fact, many of the sexually compatible species cited in [27] can be found in ruderal habitats in Switzerland [40]. In particular, several of them were detected on the railroads of Ticino (e.g. Brassica oleracea L., Brassica rapa L., Diplotaxis muralis (L.) DC., Diplotaxis tenuifolia (L.) DC., Erucastrum gallicum (Willd.) O.E. Schulz, Raphanus raphanistrum L., Rapistrum rugosum (L.) All.), and often grow sympatrically with oilseed rape $[29,30]$. For most of these species, hybridisation frequencies with oilseed rape are very low, but introgression can occur significantly with $B$. rapa (reviewed in [41]). However, under strong selection pressure such as regular herbicide application on railway infrastructure, a rare hybridisation event may have significant biological consequences. For instance, a previous study on the prickly (wild) lettuce (Lactuca serriola L.), an almost completely autogamous species with low hybridisation rates with its cultivated counterpart Lactuca sativa $\mathrm{L}$. (tens of times lower than between oilseed rape and B. rapa), showed that even rare hybridization events could have important consequences on the introgression of conventional and/or GE-traits even in absence of continued hybridization [42]. Railway habitat may act as a catalyst of gene flow from GMHT oilseed rape to its wild relatives. Moreover, $B$. rapa may act as a bridge for gene flow towards species with low hybridization 
frequencies with oilseed rape, but that are sexually compatible with B. rapa.

\section{Implication for the setting of contamination thresholds}

In Switzerland, the confinement to avoid uncontrolled spread and reproduction, and to rule out the possibility of gene flow to the wild flora, is a legal imperative, independently of the approval status of a GMO [11]. Moreover, the finding of environmental contaminations will raise the question of bearing the financial responsibility of decontamination, potential harm to the environment and the environmental follow-up of the contaminated sites, presently borne by the state. Current contamination thresholds $[12,13]$ represent a political trade-off and are unable to avoid naturalisation of weedy GE-populations established through seed loss during transportation. Our findings and considerations imply that these politically-crafted thresholds are not of sufficient biological relevance.

\section{Conclusions}

With this study, we provide early evidence of uncontrolled spread of GE-plants in the environment in Europe. In particular, we detected four feral populations of transgenic oilseed rape on Swiss railways. Although Switzerland neither grows nor imports GE-oilseed rape, it was possible to detect its feral presence at hand of a small scale project, suggesting that contamination can occur also outside the port environment as previously suggested. The ubiquity of railways in the European landscape, corroborated by positive selective pressure and widespread presence of closely related species, raise concerns about genetic contamination of natural environments. We strongly recommend that carefully adapted and systematic long term monitoring designs may be set in order to detect introduction events that can lead to rapid establishment and growing populations. We conclude that contamination thresholds are likely to be biologically insufficient to prevent environmental contamination and bear the potential to legally allow genetic pollution of the environment defeating the real purpose of the legislation, with consequences that are difficult to foresee. More specifically to Switzerland, a leading country in the acquisition of organic farming, where consumers are highly sensitive to the issue of GE-farming, the potential damage of uncontrolled spread of GEHT plants may be severe.

\section{Competing interests}

The authors declare that they have no competing interests.

\section{Authors' contributions}

NS and LDA authors contributed equally to the present work. Both authors read and approved the final manuscript.

\section{Acknowledgements}

We are grateful to Mirco Hecht and Claudia Bagutti from the Cantonal Laboratory in Basel (Switzerland) for carrying out molecular analyses, to Michele Abderhalden from the Cantonal Museum of Natural History in Lugano (Switzerland) for helping with the manuscript and allowing us to use the facility, to Claudio de Sassi and to four anonymous reviewers for their valuable comments, and to the Swiss Federal Railways for access to their infrastructure. The project was partially funded by AWEL, Section of Biological security of the Canton Zurich, the Fondation pour une Terre Humaine, and by Greenpeace Switzerland.

Received: 12 March 2012 Accepted: 26 August 2012

Published: 11 September 2012

\section{References}

1. Food and Agriculture Organisation of the United Nations: Faostat http://faostat.fao.org/site/567/DesktopDefault.aspx?PagelD=567\#ancor.

2. James C: Global Status of Commercialized Biotech/GM Crops. Ithaca NY: ISAAA; 2011. ISAAA Brief. No. 43.

3. International Service for the Acquisition of Agri-Biotech Applications: GM Approval Database. http:isaaa.org.

4. European Commission: EU register of genetically modified food and feed. http://ec.europa.eu/food/dyna/gm_register/index_en.cfm.

5. European Commission: Environmental releases of GMOs. http://gmoinfo.jrc.ec. europa.eu.

6. Swiss People and Cantons: Übergangsbestimmung zu Artikel 120 (Gentechnologie im Ausserhumanbereich). Bundesverfassung der Schweizerischen Eidgenossenschaft; SR 101, 19 April 1999 (status 1. January 2011).

7. Federal Assembly of the Swiss Parliament: Bundesgesetz über die Gentechnik im Ausserhumanbereich. SR 814.91, 1 Mars 2003 (status 28 November 2010).

8. Swiss Federal Office for Agriculture: Zugelassene und Tolerierte GVO als Futtermittel in der Schweiz. 21 February 2012 http://www.blw.admin.ch/themen/00011/00074/index.html?lang=de

9. Swiss Federal Office for Agriculture: Statistik zur Einfuhr von GVO Futtermitteln. 7 November 2011. http://www.blw.admin.ch/themen/00011/ 00074/index.html?lang=de.

10. Swiss Federal Office of Public Health: Gesuche und Bewilligungen für GVO-Erzeugnisse. 20 December 2011. http://www.bag.admin.ch/themen/ lebensmittel/04858/04863/04883/index.html?lang=de.

11. Swiss Federal Council: Verordnung über den Umgang mit Organismen in der Umwelt. SR 814.911, 10 September 2008.

12. Swiss Federal Council: Verordnung über die Produktion und das Inverkehrbringen von pflanzlichem Vermehrungsmaterial. SR 916.151, 7 December 1998 (status 1 July 2011).

13. Swiss Federal Council: Verordnung über die Produktion und das Inverkehrbringen von Futtermitteln. SR 916.307, 26 October 2011 (status 1 January 2012)

14. Ellstrand N: Dangerous liaisons? When cultivated plants mate with their wild relatives. Baltimore (MD): Johns Hopkins University Press; 2003.

15. Wolfenbarger $L L$, Phifer PR: The ecological risks and benefits of genetically engineered plants. Science 2000, 290:2088-2093.

16. Snow AA, Palma PM: Commercialization of transgenic plants: Potential ecological risks. Bioscience 1997, 47:86-96.

17. Klinger T, Elam DR, Ellstrand NC: Radish As A Model System For The Study Of Engineered Gene Escape Rates Via Crop-Weed Mating. Conserv Biol 1991, 5:531-535.

18. Ellstrand NC, Prentice HC, Hancock JF: Gene flow and introgression from domesticated plants into their wild relatives. Annu Rev Ecol Syst 1999, 30:539-563

19. Wilson AK, Latham J, Ricarda A, Steinbrecher R: Transformation-induced mutations in transgenic plants: Analysis and biosafety implications. Biotechnol Genet Eng 2006, 23:209-234.

20. Fitzlohn RG, Armstrong TT, Newstrom-Lloyd LE, Wilton AD, Cochrane M: Hybridisation within Brassica and allied genera: evaluation of potential for transgene escape. Euphytica 2007, 158:209-230.

21. Devos Y, Reheul D, De Schrijver A, Cors F, Moens W: Management of herbicide-tolerant oilseed rape in Europe: A case study on minimizing vertical gene flow. Environ Biosafety Res 2004, 3:135-148.

22. Hall L, Topinka K, Huffman J, Davis L, Good A: Pollen flow between herbicide-resistant Brassica napus is the cause of multiple-resistant $B$. napus volunteers. Weed Sci 2000, 48:688-694.

23. Knispel AL, McLachlan SM, Van Acker RC, Friesen LF: Gene flow and multiple herbicide resistance in escaped canola populations. Weed Sci 2008, 56:72-80. 
24. Schafer MG, Ross AA, Londo JP, Burdick CA, Lee EH, Travers SE, Van de Water PK, Sagers CL: The Establishment of Genetically Engineered Canola Populations in the U.S. PLoS One 2011, 6:e25736.

25. GeneWatch UK and Greenpeace International: GM Contamination Register. www.gmcontaminatioregister.org.

26. Nishizawa T, Nakajima N, Aono M, Tamaoki M, Kubo A, Saji H: Monitoring the occurence of gentically modified oilseed rape growing along a Japanese roadside: 3-year observations. Environ Biosafety Res 2009, 8:3344.

27. Devos $Y$, Hails RS, Messéan A, Perry JN, Squire GR: Feral genetically modified herbicide tolerant oilseed rape from seed import spills: are concerns scientifically justified? Transgenic Res 2012, 21:1-21.

28. Londo JP, Bautista NS, Sagers CL, Lee EH, Watrud LS: Glyphosate drift promotes changes in fitness and transgene gene flow in Canola (Brassica napus) and hybrids. Ann Bot 2010, 106:957-965.

29. Schoenenberger N, Druart P, Giorgetti-Franscini P: Note floristiche Ticinesi: la flora della rete ferroviaria con particolare attenzione alle specie avventizie. Parte I. Boll Soc Tic Sci Nat 2002, 90:127-138.

30. Schoenenberger N, Giorgetti-Franscini P: Note floristiche ticinesi: la flora della rete ferroviaria con particolare attenzione alle specie avventizie. Parte II. Boll Soc Tic Sci Nat 2004, 92:97-108

31. Janssen E, Debode F, Oger R, Hanna G, Lourme C, Kayoka Mukendi N, Ancion C, Antoine G, Arranz E, Roulez D, Berben G: Search for feral transgenic rapeseed in the environment of the Walloon Region In $1^{\text {st }}$ Global conference on GMO analysis, June 2008; Como. Edited by the European Commission Joint Research Centre. Ispra; 2008:99-100.

32. Madsen SB: Germination of buried and dry stored seeds III. 1934-60. Proc Int Seed Testing Association 1962, 27:920-928.

33. Pekrun C, Potter TC, Lutman PJW: Genotypic variation in the development of secondary dormancy in oilseed rape and its impact on the persistence of volunteer rape. In Proceedings of the 1997 Brighton Crop Protection Conference - Weeds, November1997. Edited by the British Crop Protection Council. Brighton: Farnham, Surrey; 1997:243-248.

34. Vaughan JG, Phelan JR, Denford KE: Seed studies in the Cruciferae. In The biology and chemistry of the Cruciferae. Edited by Vaughan JG, Macleod AJ, Jones BMG. London: Academic; 1976:119-144.

35. D'Andrea L, Broennimann O, Kozlowski G, Guisan A, Morin X, Keller-Senften J, Felber F: Climate change, anthropogenic disturbance and the northward range expansion of Lactuca serriola (Asteraceae). J Biogeogr 2009, 36:1573-1587.

36. von der Lippe M, Kowarik I: Crop seed spillage along roads: a factor of uncertainty in the containments of GMO. Ecography 2007, 30:483-490.

37. Warwick SI, Simard MJ, Legre A, Beckie HJ, Braun L, Zhu B, Mason P, SeguinSwartz G, Stewart CN: Hybridization between transgenic Brassica napus L. and its wild relatives: Brassica rapa L., Raphanus raphanistrum L., Sinapis arvensis L., and Erucastrum gallicum (Willd.) O. E. Schulz. Theor App/ Genet 2003, 107:528-539.

38. Squire GR, Breckling B, Dietz Pfeilstetter A, Jorgensen RB, Lecompte J, Pivard $S$, Reuter $H$, Young MW: Status of feral oilseed rape in Europe: its minor role as a GM impurity and its potential as a reservoir of transgene persistence. Environ Sci Pollut Res 2011, 18:111-115.

39. TNS Opinion \& Social: Biotechnology report. Special Eurobarometer 341. Bruxelles. 2010

40. Aeschimann D, Burdet HM: Flore de la Suisse et des territoires limitrophes. Le nouveau Binz. Griffon: Neuchâtel; 1989.

41. Devos Y, De Schrijver A, Reheul D: Quantifying the introgressive hybridisation propensity between transgenic oilseed rape and its wild/weedy relatives. Environ Monit Assess 2009, 149:303-322.

42. D'Andrea L, Felber F, Guadagnuolo R: Hybridization rates between lettuce (Lactuca sativa) and its wild relative (L. serriola) under field conditions. Environ Biosafety Res 2008, 7:61-71.

doi:10.1186/2190-4715-24-23

Cite this article as: Schoenenberger and D'Andrea: Surveying the occurrence of subspontaneous glyphosate-tolerant genetically engineered Brassica napus L. (Brassicaceae) along Swiss railways. Environmental Sciences Europe 2012 24:23.

\section{Submit your manuscript to a SpringerOpen ${ }^{\odot}$ journal and benefit from:}

- Convenient online submission

- Rigorous peer review

- Immediate publication on acceptance

- Open access: articles freely available online

- High visibility within the field

- Retaining the copyright to your article

Submit your next manuscript at $>$ springeropen.com 